\title{
Ecologically unequal exchange and ecological debt
}

\author{
Alf Hornborg ${ }^{1}$ \\ Joan Martinez-Alier \\ Lund University, Sweden \\ Autonomous University of Barcelona, Catalonia, Spain
}

\begin{abstract}
This article introduces a Special Section on Ecologically Unequal Exchange (EUE), an underlying source of most of the environmental distribution conflicts in our time. The nine articles discuss theories, methodologies, and empirical case studies pertaining to ecologically unequal exchange, and address its relationship to ecological debt.
\end{abstract}

Key words: Ecologically Unequal Exchange, ecological debt, political ecology

\section{Résumé}

Cet article présente une section spéciale sur échange écologique inégal (EUE en anglais), une source sous-jacente de la plupart des conflits de distribution environnementaux d'aujourd'hui. Les neuf articles discutent des théories, des méthodes et des études de cas empiriques relatives à l'échange écologique inégal, et aborder sa relation avec la dette écologique.

Mots clés: l'échange écologique inégal, la dette écologique, l'écologie politique

\section{Resumen}

Este artículo presenta una sección especial sobre el intercambio ecológícamente desigual (EUE en inglés), que es una causa subyacente de la mayoría de los conflictos de distribución ambiental en la actualidad. Los artículos discuten nuevas teorías, métodos y estudios de casos empíricos sobre el intercambio ecológicamente desigual, y discuten su relación con la deuda ecológica.

Palabras clave: comercio ecológicamente desigual, deuda ecológica, ecología política

The articles in this Special Section of the Journal of Political Ecology are based on papers presented at a workshop on Ecologically unequal exchange and ecological debt organized in Lund, Sweden, March 27-28th, 2014. The workshop was part of the project Environmental Justice Organizations, Liabilities, and Trade (EJOLT), and most of the contributors were EJOLT project participants. EJOLT was a Science-in-Society FP7 project funded by the European Commission that ran from 2011 to 2015, coordinated by the ICTA, Universitat Autonoma de Barcelona. An important legacy is the EJAtlas (www.ejatlas.org) that keeps growing after the end of EJOLT, logging 1,900 conflicts worldwide by November 2016 (see Temper et al. 2015). Another main permanent outcome of EJOLT was the production of 23 reports on several thematic and cross-cutting issues of environmental justice (fossil fuels and minerals, tree plantations, nuclear energy, industrial waste; economic valuation of liabilities; legal instruments for the EJOs [Environmental justice organizations]; human health), as well as video documentaries, policy briefs, academic articles, special issues, on-line courses, and training materials (available at www.ejolt.org). EJOLT brought together twenty-three academic or activist groups from Europe, Africa, Latin America and Asia to advance knowledge on a problem of great interest to society, namely: what are the underlying causes of increasing ecological distribution conflicts at different scales, and how can such conflicts be turned into forces for environmental sustainability?

${ }^{1}$ Dr. Alf Hornborg, Professor, Human Ecology Division, Lund University, Sweden. Email: alf.hornborg "at" hek.lu.se. Dr. Joan Martinez-Alier, Emeritus Professor, ICTA, Universitat Autonoma de Barcelona, Catalonia, Spain. Email: joan.martinez.alier "at" uab.cat. Acknowledgements: EJOLT FP7 project and ENVJUSTICE Advanced Grant from the ERC awarded to Joan Martinez-Alier, supported by the European Research Council (ERC). JPE editor Simon Batterbury. This is the introductory article in Alf Hornborg and Joan Martinez-Alier (eds.) 2016. "Ecologically unequal exchange and ecological debt", Special Section of the Journal of Political Ecology 23: 328-491. 
Central concepts in EJOLT were Ecological Debts (or Environmental Liabilities) and Ecologically Unequal Exchange (EUE). We focused on the use of these concepts in sustainability sciences and in environmental activism and policy-making. It was natural for the conveners of the Lund workshop of March 2014 to turn to the Journal of Political Ecology for publication of the proceedings. The concept of political ecology is easy to identify with for academic researchers in fields such as ecological economics or environmental sociology, on the one hand, and for environmental justice activists, on the other. What joins us all is concern with ecological distribution conflicts and their outcomes (Martinez-Alier 2002). Authors in this issue have different disciplinary backgrounds, from anthropology, history, sociology, the study of social metabolism, ecological economics, and international law. Or, they are non-disciplined activists. They all find themselves at home in political ecology.

Ecologically unequal exchange is an underlying source of most environmental distribution conflicts in our time. In the invitation to the workshop, we encouraged participants to discuss theories, methodologies, and empirical case studies pertaining to ecologically unequal exchange, and to address its relation to the concept of ecological debt.

In ecological economics, the environmental justice movement, and political ecology in general, there is a growing consensus that mainstream economic discourse and policy is unable to conceptualize ecologically unequal exchange. Conventional economic analyses of trade tend only to discern the flows of money, but by considering biophysical metrics such as material and energy flows, and embodied labor, water and land, we can identify asymmetric flows of resources obscured by the apparent reciprocity of market prices. The unequal exchange of embodied labor time has been revealed by economists working in the Marxian tradition (e.g., Emmanuel 1972; cf. Simas et al. 2015); whereas the asymmetric flows of embodied land indicate that there is also an ecologically unequal exchange (Hornborg 1998, 2013; Jorgenson and Clark 2009). Note that the identification of such asymmetric flows of biophysical resources is not tantamount to arguing that there are asymmetric flows of 'surplus value.' Value is a concept deriving from economics and tends to constrain our thinking about how material resource flows relate to flows of money. For the same reason it is questionable to argue that biophysical resources are 'underpaid', as this implies that they might have a correct price, which would make the exchange equal or fair. Such ways of thinking cannot be reconciled with the Entropy Law (the Second Law of Thermodynamics) and thus pose a serious challenge to economics (Georgescu-Roegen 1971).

The factor of production referred to as 'land' can be subdivided into raw materials, energy, and eco-productive space (Dorninger and Hornborg 2015). Recent research has shown that three core regions of the modern world-system--the United States, the European Union, and Japan--are all net importers of both raw material equivalents and embodied energy (Lenzen et al. 2012, 2013) as well as embodied space (Yu et al. 2013). These asymmetric resource flows become visible only when we replace the monetary metrics of mainstream economics with biophysical metrics. They contribute to growing inequalities between affluent core regions of the world-system, on the one hand, and impoverished extractive economies in the periphery, on the other. Some underpopulated countries relying on primary exports have managed to become prosperous (e.g. Australia, Canada) but these are exceptions. The existence of historically privileged and sparsely populated nations richly endowed with natural resources has enabled some extractive zones of the world-system to escape impoverishment, but EUE has for centuries contributed to global polarization and the impoverishment of large segments of the world's population and landscapes. Periodic bonanzas as in South America and parts of Africa between 2000 and 2008, or perhaps 2012, soon turned into economic crises. The uneven accumulation of capital in the form of technological infrastructure is visible even on satellite images of global night-time illumination. Yet the mechanisms underlying this growing economic polarization in world society remain largely outside the field of vision of neoclassical economics.

Ecologically unequal exchange is a concept developed in academia and particularly in ecological economics as a challenge to mainstream economic theories of trade (Hornborg 1998). Much before this, and without the present analytic refinements, it was deployed with more robust language (such as 'plunder', or in German, Raubwirtschaft). The concept has become common currency among the EJOs. More precision in the analysis and careful quantification, as demonstrated by the articles in this Special 
Section, could help the cause of environmental justice. The grassroots concept of "ecological debt" (Martinez-Alier et al. 2014), on the other hand, was born from the fertile minds of some EJOs around 1990, and was later taken up by academics (Martinez-Alier 2002; Warlenius et al. 2015a, 2015b). It brings together the awareness of plunder from international trade and environmental load displacement, and the complaints over the disproportionate use of the oceans and the atmosphere by the rich to dispose of excessive amounts of carbon dioxide. It is a powerful concept for climate justice activists and relevant in wider circles, emphasized in Naomi Klein's best-seller This changes everything (2014) and in Pope Francis' 2015 encyclical Laudato si (paragraphs 51 and 52, 2015).

Several papers in this collection use statistics on international trade (in physical but also in monetary terms), the production of greenhouse gases, or other indicators of social metabolism (e.g. the HANPP, Human Appropriation of Net Primary Production) as inputs leading to discussions on political power and ecological distribution. In this way, this Special Section helps to answer the famous question, "where is the ecology in political ecology?" (Walker 2015).

In the first paper in this collection, Andrew Jorgenson (2016) reviews his own work on what he calls "weighted export flows", statistically quantifying the extent to which the exports of different nations are destined for less- or more-developed countries. In different studies, Jorgenson has shown that lessdeveloped countries that export large volumes of natural resources to more-developed countries tend to have lower levels of consumption and carbon dioxide emissions per capita and to be more likely to experience adverse environmental effects such as deforestation and loss of biodiversity. He has found that the more affluent and militarily powerful nations are more likely to displace environmental pressures both the extraction of resources and the disposal of waste - to less-developed and militarily weaker nations. Such displacements, exemplified by a range of environmentally destructive activities in lessdeveloped countries, tend to be exacerbated by rising levels of foreign direct investments, the increase of which is ultimately prompted by austerity measures designed by global financial institutions. Jorgenson finally expresses hopes that global environmental movements will be able to reduce the environmental degradation resulting from ecologically unequal exchange and environmental load displacement.

Andreas Mayer and Willi Haas (2016) analyze published data on the social metabolism of 177 countries between 1950 and 2010. In comparing domestic extraction, imports, and exports, they find that core areas of the world-system such as highly industrialized countries in Western Europe, the United States, and Japan have been most dependent on material imports and the concomitant displacement of environmental pressures to other countries. Conversely, the Physical Trade Balances of peripheral regions of the world-system such as Southern and Central Asia, sub-Saharan Africa, Latin America, and Oceania tend to be negative, as countries in these areas exported large shares of their natural resources. Mayer and Haas conclude that countries that have succeeded in externalizing environmental pressures have accrued an ecological debt to other nations.

Climate change is a growing example of 'environmental load displacement.' Rikard Warlenius (2016) links the concepts of ecologically unequal exchange and ecological debt by observing that the first denotes a "flow" and the second a "stock" perspective. To include greenhouse gas emissions in such calculations of the relative ecological debts of nations, Warlenius proposes the concept of unequal sink appropriation. Although greenhouse gas emissions have global consequences, this concept makes it possible to estimate the environmental performance of individual nations in terms of their relative responsibility for climate change.

Jordi Jaria i Manzano et al. (2016) endorse the notion of ecological debt as an acknowledgement of the inequalities and injustices of the current world order. They argue that the concept requires a rethinking and the remaking of international law from the perspective of less affluent and marginalized countries. They discuss the problems of offering monetary compensation for past ecological damage, emphasizing that such compensation does not mean that new inequalities and injustices will not be generated in the future. The concept of ecological debt should thus imply an ambition to use international law to alleviate structural asymmetries in the world economy.

Christian Dorninger and Nina Eisenmenger (2016) take a closer look at the biophysical trade relations of Argentina, Bolivia, and Brazil with other countries, categorized as "core" and "non-core", 
between 1962 and 2011. They conclude that all the three countries have negative Physical Trade Balances, but Argentina and Brazil more so than Bolivia, which has only had a limited involvement in international trade. In the case of Argentina and Brazil, it is clearly evident that the liberalization of trade has contributed to the deterioration of physical and monetary trade balances. Trends were such that despite the large excess of exports over imports in tons, the three countries could no longer pay for imports in the years after 2013-2015.

Leah Temper (2016) investigates the distribution of biomass, measured as the HANPP, in the Tana Delta area on the coast of Kenya, a region potentially subjected to land-grabbing for the large-scale production of agro- and biofuels and other development projects. The HANPP has usually been used as an indicator of pressure on biodiversity. Temper asks: which human groups are getting the largest share of the HANPP? In order to understand what these development schemes would mean in biophysical and political ecological terms, Temper considers what conflicts over biomass can be anticipated between corporations, wildlife, and indigenous groups of pastoralists, farmers, and fishermen. In a sugar economy, while biomass production and the proportion of it appropriated by humans would increase, less biomass would be available for local indigenous communities and biodiversity, and much of it would be exported in the form of sugar, ethanol, or even electricity.

Jutta Kill (2016) suggests that voluntary certification schemes may serve not so much to preclude as to maintain ecologically unequal exchange. Focusing in detail on the case of the Forest Stewardship Council's endorsement of industrial tree plantations for pulpwood production in Brazil, she shows how certification schemes can be used to boost the power of corporate interests. Measures ostensibly taken to promote sustainability may thus be coopted to safeguard the continuation of highly unsustainable practices. Kill's case study illustrates the widespread doubt that rhetorically stated goals such as sustainability and environmental justice are genuinely compatible with corporate interests.

Martin Oulu (2016) summarizes some central tenets of EUE theory and relates the asymmetric global exchange of resources to the structure of the capitalist world-economy and its ideology of free trade. These international structures, he shows, are promoted by the policies of nation states and other powerful institutions. Oulu proposes a set of criteria for assessing the extent to which EUE is acknowledged in public policy, and exemplifies this by briefly examining the EU Raw Materials Initiative (which in fact promotes EUE) from this perspective. Although the prospects for translating concerns over EUE into mainstream policy seem slim, he concludes by offering the hope that global solidarity will be enhanced not by disaster, but by design.

Finally, Joan Martinez-Alier and colleagues (2016) compare the social metabolism of India and South America since 1970 and trace the increase and nature of ecological distribution conflicts in the two areas to changes in social metabolism. South American countries tend to have a negative Physical Trade Balance and to have reached a higher level of resource extraction per capita. In contrast, India as a whole is not a net exporter of natural resources and remains at a lower (although rapidly increasing) level of material throughput per capita. India experiences asymmetric material flows internally, exploiting some states as providers of raw materials in a sort of "internal colonialism." The authors also consider statistics from the EJAtlas on ecological distribution conflicts, and killings of those opposed to major resource projects in 2016, and conclude that marginalized indigenous groups are disproportionally involved in struggles for environmental justice.

Taken together, these nine articles demonstrate that the critical study of environmental justice issues and ecologically unequal exchange has developed an impressive range of largely quantitative methods for documenting and establishing the occurrence of structural inequalities in the distribution of negative environmental impacts. The empirical data and theoretical analyses presented in this collection underline the urgency of addressing the political ecology of global economic processes and their local repercussions. The data and the analyses also give some support to the global movement for environmental justice. 


\section{Environmentally Unequal Exchange and ecological debt, edited by Alf Hornborg and Joan Martinez-Alier}

1. Andrew Jorgenson - The sociology of ecologically unequal exchange, foreign investment dependence and environmental load displacement: summary of the literature and implications for sustainability

2. Andreas Mayer and Willi Haas - Accumulating resource flows to quantify the ecological debt

3. Rikard Warlenius - Linking ecological debt and ecologically unequal exchange: stocks, flows, and unequal sink appropriation

4. Jordi Jaria i Manzano, Antonio Cardesa-Salzmann, Antoni Pigrau and Susana Borràs Measuring environmental injustice: how ecological debt defines a radical change in the international legal system

5. Christian Dorninger and Nina Eisenmenger - South America's biophysical involvement in international trade: the physical trade balances of Argentina, Bolivia, and Brazil in the light of ecologically unequal exchange

6. Leah Temper - Who gets the HANPP (Human Appropriation of Net Primary Production)? Biomass distribution and the 'sugar economy' in the Tana Delta, Kenya

7. Jutta Kill - The role of voluntary certification in maintaining the ecologically unequal exchange of wood pulp: the case of the Forest Stewardship Council's certification of industrial tree plantations in Brazil

8. Martin Oulu - Core tenets of the theory of ecologically unequal exchange

9. Joan Martinez-Alier, Federico Demaria, Leah Temper and Mariana Walter - Changing social metabolism and environmental conflicts in India and South America

\section{References}

Dorninger C. and N. Eisenmenger. 2016. South America's biophysical involvement in international trade: the physical trade balances of Argentina, Bolivia, and Brazil in the light of ecologically unequal exchange. Journal of Political Ecology 23: 394-409.

Dorninger, C. and A. Hornborg. 2015. Can EEMRIO analyses establish the occurrence of ecologically unequal exchange? Ecological Economics 119: 414-418.

Emmanuel, A. 1972. Unequal exchange: a study of the imperialism of trade. New York: Monthly Review Press.

Hornborg, A. 1998. Towards an ecological theory of unequal exchange: articulating world system theory and ecological economics. Ecological Economics 25(1):127-136.

Hornborg, A. 2013. Global ecology and unequal exchange: fetishism in a zero-sum world. London: Routledge.

Jaria i Manzano, J., A. Cardesa-Salzmann, A. Pigrau and S. Borràs. 2016. Measuring environmental injustice: how ecological debt defines a radical change in the international legal system. Journal of Political Ecology 23: 381-393.

Jorgenson A.K. 2016. The sociology of ecologically unequal exchange, foreign investment dependence and environmental load displacement: summary of the literature and implications for sustainability. Journal of Political Ecology 23: 334-349.

Jorgenson, A.K. and B. Clark (eds.). 2009. Special issue: Ecologically Unequal Exchange in comparative perspective. International Journal of Comparative Sociology 50(3-4): 211-409.

Kill, J. 2016. The role of voluntary certification in maintaining the ecologically unequal exchange of wood pulp: the case of the Forest Stewardship Council's certification of industrial tree plantations in Brazil. Journal of Political Ecology 23: 434-445.

Klein, N. 2014. This changes everything: capitalism versus the climate. London: Allen Lane. 
Lenzen, M., K. Keiichiro, D. Moran and A. Geschke. 2012. Mapping the structure of the world economy. Environmental Science and Technology 46(15): 8374-8381.

Lenzen, M, D. Moran, K. Keiichiro and A. Geschke. 2013. Building EORA: a global multi-regional inputoutput database at high country and sector resolution. Economic Systems Research 25(1): 20-49. $\underline{\text { draft }}$

Martinez-Alier, J. 2002. The environmentalism of the poor: a study of ecological conflicts and valuation. Cheltenham: Edward Elgar. Ch.1, 2

Martinez-Alier, J., F. Demaria, L. Temper and M. Walter 2016. Trends of social metabolism and environmental conflicts: a comparison between India and Latin America. Journal of Political Ecology 23: 467-491.

Martinez-Alier, J., I. Anguelovski, P. Bond, D. Del Bene, F. Demaria, J.F. Gerber, L. Greyl, W. Haas, H. Healy, V. Marín-Burgos, G. Ojo, M.F. Porto, L. Rijnhout, B. Rodríguez-Labajos, J. Spangenberg, L. Temper, R. Warlenius and I. Yánez. 2014. Between activism and science: grassroots concepts for sustainability coined by environmental justice organizations. Journal of Political Ecology 21: 19-60.

Mayer A. and W. Haas. 2016. Cumulative material flows provide indicators to quantify the ecological debt. Journal of Political Ecology 23: 350-363.

Oulu, M. 2016. Core tenets of the theory of ecologically unequal exchange. Journal of Political Ecology 23: 446-466.

Pope Francis 2015. Care for our common home. Encyclical Letter Laudato Si' of the Holy Father Francis. The Vatican.

Simas, M., R. Wood, and E. Hertwich 2015. Labor embodied in trade: the role of labor and energy productivity and implications for greenhouse gas emissions. Journal of Industrial Ecology 19(3): 343-356.

Temper L. 2016. Who gets the HANPP (Human Appropriation of Net Primary Production)? Biomass distribution and the 'sugar economy' in the Tana Delta, Kenya. Journal of Political Ecology 23: 410-433.

Temper, L., D. Del Bene and J. Martinez-Alier. 2015. Mapping the frontiers and front lines of global environmental justice: the EJAtlas. Journal of Political Ecology 22: 255-278.

Walker, P. 2005. Political ecology: where is the ecology? Progress in Human Geography 29(1): $73-82$.

Warlenius, R. 2016. Linking ecological debt and ecologically unequal exchange: stocks, flows, and unequal sink appropriation. Journal of Political Ecology 23: 364-380.

Warlenius, R., G. Pierce and V. Ramasar. 2015a. Reversing the arrow of arrears: the concept of "ecological debt" and its value for environmental justice. Global Environmental Change 30: 2130.

Warlenius, R., G. Pierce, V. Ramasar, E. Quistorp, J. Martínez-Alier, L. Rijnhout and I. Yanez. $2015 b$. Ecological debt: history, meaning and relevance for environmental justice. EJOLT Report No. 18.

Yu, Y., K. Feng and K. Hubacek. 2013. Tele-connecting local consumption to global land use. Global Environmental Change 23(5):1178-1186. 